\title{
Short communication: Effects of butyrate supplementation on the productivity of lactating dairy cows fed diets differing in starch content
}

\author{
K. Izumi, ${ }^{1}$ R. Fukumori, ${ }^{2}$ S. Oikawa, ${ }^{2}$ and M. Oba ${ }^{3 *}$ (i) \\ ${ }^{1}$ Department of Sustainable Agriculture, College of Agriculture, Food and Environment Sciences, Rakuno Gakuen University, Ebetsu, \\ Japan 069-8501 \\ ${ }^{2}$ Department of Veterinary Medicine, School of Veterinary Medicine, Rakuno Gakuen University, Ebetsu, Japan 069-8501 \\ ${ }^{3}$ Department of Agricultural, Food and Nutritional Science, University of Alberta, Edmonton, AB, Canada T6G 2P5
}

\section{ABSTRACT}

The objective of this study was to evaluate the effects of butyrate supplementation on the dry matter intake (DMI), milk production, and blood metabolites of lactating dairy cows fed diets differing in starch content. Eight Holstein cows after peak lactation $(58.6 \pm 9.96$ $\mathrm{d}$ in milk; mean $\pm \mathrm{SD}$ ) were blocked by parity and assigned to 1 of 2 Latin squares $(4 \times 4)$ balanced for carryover effects with a $2 \times 2$ factorial arrangement of treatments. Treatments differed by dietary starch content (20.6 vs. $27.5 \%$ ) and butyrate supplementation (butyrate vs. control) with 21-d periods. Experimental diets contained 36 and $30 \%$ corn silage, 18 and $15 \%$ grass silage, and 46 and $55 \%$ concentrates, respectively, for low starch and high starch diets, on a dry matter (DM) basis. Butyrate was provided as Gustor BP70 WS (Norel S.A., Madrid, Spain), containing 70\% sodium butyrate and $30 \%$ fatty acid mixture, at $2 \%$ of dietary $\mathrm{DM}$ (providing butyrate at $1.1 \%$ of dietary DM), and control premix contained $70 \%$ wheat bran and $30 \%$ fatty acid mixture. Interaction effects between dietary starch content and butyrate supplementation were not observed for primary response variables, and milk yield was not affected by treatment. Butyrate supplementation increased serum $\beta$-hydroxybutyrate concentration compared with control (0.706 vs. $0.930 \mathrm{mM})$, but did not exceed $1.2 \mathrm{~m} M$, a commonly accepted value for subclinical ketosis, and DMI was not affected. Cows fed butyrate had increased milk fat content (4.58 vs. $4.37 \%$ ) and milk fat yield (1.51 vs. $1.42 \mathrm{~kg} / \mathrm{d}$ ), tended to have increased $4 \%$ fat-corrected milk yield (35.9 vs. $34.3 \mathrm{~kg} / \mathrm{d}$ ) and feed efficiency (1.56 vs. $1.50 ; 4 \%$ fatcorrected milk yield/DMI), and had decreased milk urea nitrogen (MUN) concentration (10.8 vs. $11.7 \mathrm{mg} /$

Received June 16, 2019.

Accepted July 18, 2019.

*Corresponding author: moba@ualberta.ca
dL) compared with control. Cows fed high starch diets tended to have increased DMI (23.3 vs. $22.5 \mathrm{~kg} / \mathrm{d}$ ), increased milk protein yield (1.13 vs. $1.05 \mathrm{~kg} / \mathrm{d})$, and decreased MUN concentration (10.3 vs. $12.2 \mathrm{mg} / \mathrm{dL}$ ). Inclusion of butyrate at $1.1 \%$ of dietary DM increased milk fat production and decreased MUN concentration without affecting DMI or increasing the risk of subclinical ketosis, regardless of dietary starch content.

Key words: butyrate, milk fat production, dietary starch content, milk urea nitrogen

\section{Short Communication}

Butyrate is one of the major VFA produced in the rumen and promotes development of rumen epithelial tissues (Sakata and Tamate, 1978; Simmons et al., 2009); many studies have evaluated the effect of butyrate administration on the development of the rumen and gastrointestinal tract in calves (Górka et al., 2011; Wanat et al., 2015; Górka et al., 2018). For lactating dairy cows, butyrate is used for de novo fatty acid synthesis in the mammary gland (Dils, 1986), and butyrate administration is expected to increase milk fat production. High starch diets, commonly fed to highproducing dairy cows, cause rapid acid accumulation in the rumen and decrease rumen $\mathrm{pH}$, often leading to diet-induced milk fat depression (Harvatine et al., 2009; Kmicikewycz et al., 2015). Considering the effect of butyrate on promoting milk fat synthesis, adding butyrate to a high starch diet for high-yielding dairy cows may reduce the risk of milk fat depression. However, previous research is not consistent; some have reported that butyrate infusion or supplementation increased milk fat production (Rook et al., 1965; Huhtanen et al., 1993; Herrick et al., 2017) but others reported no effects (Herrick et al., 2018) or negative effects (Urrutia et al., 2019), and the discrepancy may be related to different dietary starch contents among the studies. The objective of the current study was to evaluate the 
effect of butyrate supplementation on the productivity and blood metabolites of lactating dairy cows fed diets differing in starch content.

Cows used in this study were housed at Rakuno Gakuen Field Education and Research Center (Ebetsu, Hokkaido, Japan), and all procedures were approved by the Animal Experiment Committee of Rakuno Gakuen University.

Eight Holstein cows after peak lactation $(1.9 \pm 0.99$ parity, $609 \pm 99.4 \mathrm{~kg}$ of BW, $3.06 \pm 0.22 \mathrm{BCS}, 58.6 \pm$ 9.96 DIM; mean $\pm \mathrm{SD}$ ), including 4 primiparous and 4 multiparous cows, were used. This study was conducted from September to December 2018. Cows were housed in individual tie stalls covered with rubber mattresses, on which wheat straw was spread as bedding. Cows were blocked by parity and assigned to 1 of 2 Latin squares $(4 \times 4)$ balanced for carryover effects with a $2 \times$ 2 factorial arrangement of treatments. Each period was $21 \mathrm{~d}$, consisting of a 16-d diet adaptation period and a 5 -d data and sample collection period. Treatments were dietary starch content (20.6 vs. 27.5\%) and butyrate supplementation (butyrate vs. control). Experimental diets contained 36 and $30 \%$ corn silage, 18 and 15\% grass silage, and 46 and $55 \%$ concentrates, respectively, for low starch (LS) and high starch (HS) diets, on a DM basis (Table 1). Butyrate was provided as Gustor BP70 WS (Norel S.A., Madrid, Spain), containing 70\% sodium butyrate and 30\% fatty acid mixture, at $2 \%$ of dietary DM (providing butyrate at $1.1 \%$ of dietary $\mathrm{DM}$ ), and control premix contained $70 \%$ wheat bran and $30 \%$ fatty acid mixture with a similar fatty acid profile to Gustor BP70 WS. Diets were formulated using the Agricultural Modeling and Training System model (version 4.10.2; AMTS LLC, Groton, NY) for cows with $620 \mathrm{~kg}$ BW producing at least $34 \mathrm{~kg} / \mathrm{d}$ of milk with $3.9 \%$ fat and $3.2 \%$ protein. All diets were formulated to contain similar CP concentration. Cows were individually fed the experimental diets as TMR ad libitum to allow for approximately $8 \%$ refusals. The diets were fed once daily at $1200 \mathrm{~h}$, and feed refusals were removed at $1100 \mathrm{~h}$ the following day. Cows were provided continuous access to water, and milked twice daily at 0630 and $1730 \mathrm{~h}$.

The weight of feed offered and orts was recorded daily. From d 17 to 19 of each period, forage (grass and corn silage) and concentrate samples were collected daily, and orts samples were collected daily from each cow to determine the DMI and chemical composition of diets. Daily samples were stored in a refrigerator and composited for each period.

Milk yield was measured from d 17 to 19 of each period, and milk samples were collected from 6 consecutive milkings for $3 \mathrm{~d}$. Milk samples were analyzed individually for fat, protein, lactose, SNF, and MUN by the Hokkaido Dairy Milk Recording and Testing Association using mid-infrared spectrophotometry (AOAC International, 2000). Weighed milk composition values were calculated daily and averaged to obtain 1 value per cow per period. The efficiency of milk production was calculated as kilograms of milk and 4\% FCM yield per kilogram of DMI. Cows' BW and BCS were measured immediately before the start of the study; BCS was determined using a 5-point scale (Ferguson et al., 1994).

Blood samples were collected by tail venipuncture at 0,3 , and $6 \mathrm{~h}$ relative to feeding on d 19 of each period. Blood samples $(15 \mathrm{~mL})$ were collected in blank $(10 \mathrm{~mL})$ and heparinized $(5 \mathrm{~mL})$ evacuated tubes (Terumo, To-

Table 1. Ingredients and chemical composition of experimental diets ${ }^{1}$

\begin{tabular}{|c|c|c|c|c|}
\hline \multirow[b]{2}{*}{ Item } & \multicolumn{2}{|c|}{ Low starch diets } & \multicolumn{2}{|c|}{ High starch diets } \\
\hline & $\mathrm{CON}$ & BUT & $\mathrm{CON}$ & BUT \\
\hline \multicolumn{5}{|l|}{ Ingredient, $\%$ of diet DM } \\
\hline Corn silage & 36.0 & 36.0 & 30.0 & 30.0 \\
\hline Grass silage & 18.0 & 18.0 & 15.0 & 15.0 \\
\hline Steam-flaked corn & 13.1 & 13.1 & 27.0 & 27.0 \\
\hline Beet pulp & 13.0 & 13.0 & 7.55 & 7.55 \\
\hline Soybean meal & 12.7 & 12.7 & 13.0 & 13.0 \\
\hline Corn gluten meal & 1.72 & 1.72 & 1.78 & 1.78 \\
\hline Mineral mix ${ }^{2}$ & 2.09 & 2.09 & 2.15 & 2.15 \\
\hline Premix-CON ${ }^{3}$ & 2.00 & — & 2.00 & - \\
\hline Butyrate supplement $^{4}$ & - & 2.00 & - & 2.00 \\
\hline Premium fat $\mathrm{A}^{5}$ & 0.67 & 0.67 & 0.69 & 0.69 \\
\hline Sodium bicarbonate & 0.45 & 0.45 & 0.46 & 0.46 \\
\hline Salt white & 0.22 & 0.22 & 0.23 & 0.23 \\
\hline Vitamin $\operatorname{mix}^{6}$ & 0.07 & 0.07 & 0.07 & 0.07 \\
\hline \multicolumn{5}{|l|}{ Chemical composition } \\
\hline DM, \% & 44.3 & 45.4 & 48.6 & 48.7 \\
\hline $\mathrm{CP}, \%$ of DM & 16.5 & 16.6 & 16.6 & 16.3 \\
\hline $\mathrm{ADF}, \%$ of DM & 22.5 & 21.7 & 19.0 & 18.8 \\
\hline NDF, $\%$ of DM & 32.7 & 31.3 & 28.0 & 27.4 \\
\hline Forage NDF, \% of DM & 26.0 & 24.8 & 21.4 & 21.5 \\
\hline Starch, \% of DM & 20.7 & 20.5 & 27.6 & 27.3 \\
\hline Ether extract, $\%$ of DM & 3.73 & 3.77 & 3.78 & 3.82 \\
\hline Ash, $\%$ of DM & 7.36 & 8.20 & 6.85 & 6.61 \\
\hline $\mathrm{NFC}_{2} \%$ of DM & 40.0 & 41.4 & 45.0 & 46.1 \\
\hline $\mathrm{NE}_{\mathrm{L}},{ }^{7} \mathrm{Mcal} / \mathrm{kg}$ of DM & 1.65 & 1.69 & 1.70 & 1.74 \\
\hline ME allowable milk, ${ }_{7}^{7} \mathrm{~kg} / \mathrm{d}$ & 35.0 & 35.5 & 37.5 & 38.0 \\
\hline MP allowable milk, ${ }^{7} \mathrm{~kg} / \mathrm{d}$ & 34.5 & 34.1 & 36.5 & 36.2 \\
\hline
\end{tabular}

${ }^{1} \mathrm{BUT}=$ diet containing butyrate; $\mathrm{CON}=$ control diet.

${ }^{2}$ Contained $25.5 \% \mathrm{Ca}, 2.5 \% \mathrm{P}, 7.0 \% \mathrm{Mg}, 0.1 \% \mathrm{~S}, 0.2 \% \mathrm{Na}, 0.3 \% \mathrm{Cl}$, $570.0 \mathrm{mg} / \mathrm{kg} \mathrm{Fe}, 640.0 \mathrm{mg} / \mathrm{kg} \mathrm{Zn}, 59.0 \mathrm{mg} / \mathrm{kg} \mathrm{Cu}, 570.0 \mathrm{mg} / \mathrm{kg} \mathrm{Mn}$, $5.0 \mathrm{mg} / \mathrm{kg} \mathrm{Co}$, and $6.0 \mathrm{mg} / \mathrm{kg} \mathrm{I}$.

${ }^{3}$ Contained $70.0 \%$ wheat bran and $30.0 \%$ fatty acid mixture $(1.1 \%$ C14:0, 42.3\% C16:0, 55.4\% C18:0, 0.9\% C18:1, and 0.2\% C18:2).

${ }^{4}$ Gustor BP 70 WS contained $70.0 \%$ sodium butyrate and $30.0 \%$ fatty acid mixture (1.0\% C14:0, 43.0\% C16:0, 55.0\% C18:0, and 1.0\% C18:1).

${ }^{5}$ Premium fat A (Shiraishi Calcium Kaisha Ltd., Osaka, Japan).

${ }^{6}$ Contained $6,803 \mathrm{kIU} / \mathrm{kg}$ of vitamin A, 1,361 kIU/kg of vitamin D, and 40,304 IU $/ \mathrm{kg}$ of vitamin $\mathrm{E}$.

${ }^{7}$ Estimated from NRC (2001). 
kyo, Japan). The blank tubes were allowed to clot at room temperature for $45 \mathrm{~min}$. Heparinized tubes were immediately placed on ice, and aprotinin (500 Kallikrein inhibitor units/mL of blood; Sigma-Aldrich Inc., Tokyo, Japan) was added as an inhibitor of peptide degradation. The tubes were then centrifuged at 1,800 $\times g$ for 15 min at $4^{\circ} \mathrm{C}$. The harvested serum and plasma were stored at $-80^{\circ} \mathrm{C}$ until analysis to determine serum concentrations of BHB, free fatty acids, glucose, urea nitrogen (UN) and plasma concentration of insulin.

Diet ingredients, fresh TMR, and refusals were dried in a $55^{\circ} \mathrm{C}$ forced-air oven for $72 \mathrm{~h}$ and then ground through a $1 \mathrm{~mm}$ screen. The samples were sent to Cumberland Valley Analytical Services (Hagerstown, MD), and analyzed for DM (AOAC International, 2000), ash (AOAC International, 2000), NDF (Van Soest et al., 1991), ADF (AOAC International, 2000), starch (Hall, 2009), ether extract (AOAC International, 2006), and CP (AOAC International, 2000). The ingredients and analyzed chemical compositions of each diets are presented in Table 1.

Serum concentrations of metabolites were measured using an automatic analyzer (AU680; Olympus Corp., Tokyo, Japan) with their commercially available kits for BHB (Wako Auto Kit 3-HB; Fujifilm Wako Pure Chemical Corp., Osaka, Japan), free fatty acids (NEFA-HRII; Fujifilm Wako Pure Chemical Corp.), glucose (Cicaliquid GLU; Kanto Chemical, Co., Inc., Tokyo, Japan), and UN (N-assay BUN-L; Nittobo Medical Co. Ltd., Tokyo, Japan). Plasma insulin concentrations were measured using a solid-phase competition immunoassay with bovine insulin (Sigma-Aldrich Inc.), europium-labeled bovine insulin, and polystyrene microtiter strips coated with anti-guinea pig $\gamma$-globulin as described by Masuda et al. (2019). The intra-assay CV was $4.2 \%$, and the detection limit was $0.055 \mathrm{ng} / \mathrm{mL}$.

All data were analyzed using the Fit model procedure of JMP (version 13.2.1; SAS Institute Inc., Cary, NC). For variables not measured over time, such as DMI, milk yield and components, and feed efficiency, the model included the fixed effects of dietary starch content, butyrate supplementation, their interaction, period, and parity, and the random effects of cow. For variables measured over time, such as serum metabolites, the model included the fixed effects of dietary starch content, butyrate supplementation, collection time as a repeated measure, starch content and butyrate interaction, starch content and time interaction, butyrate and time interaction, and starch content, butyrate and time interaction, period, parity, and the random effects of cow nested in parity with compound symmetry as a covariant structure. Differences were considered to be significant at $P<0.05$ and to have a tendency at $P<0.10$.

Dry matter intake tended to be higher for cows fed the HS diets than for those fed the LS diets $(P=0.06$; Table 2), but butyrate treatment did not affect DMI. Dietary treatment did not affect milk yield. However, butyrate supplementation tended to increase $4 \% \mathrm{FCM}$ yield $(P=0.08)$ and feed efficiency $(4 \% \mathrm{FCM} / \mathrm{DMI}$; $P=0.08)$ compared with control diets, regardless of dietary starch content. Milk fat concentration and yield were higher for cows fed butyrate diets than for those fed control diets $(P<0.05)$, but were not affected by

Table 2. Effects of butyrate supplementation and dietary starch content on DMI, milk production, and feed efficiency of lactating dairy cows ${ }^{1}$

\begin{tabular}{|c|c|c|c|c|c|c|c|c|}
\hline \multirow[b]{2}{*}{ Item } & \multicolumn{2}{|c|}{ Low starch } & \multicolumn{2}{|c|}{ High starch } & \multirow[b]{2}{*}{ SEM } & \multicolumn{3}{|c|}{$P$-value } \\
\hline & $\mathrm{CON}$ & BUT & $\mathrm{CON}$ & BUT & & Starch & BUT & INT \\
\hline DMI, kg/d & 22.7 & 22.2 & 23.0 & 23.6 & 0.86 & 0.06 & 0.95 & 0.22 \\
\hline \multicolumn{9}{|l|}{ Yield, $\mathrm{kg} / \mathrm{d}$} \\
\hline Milk & 32.5 & 32.2 & 33.1 & 33.8 & 1.24 & 0.21 & 0.78 & 0.59 \\
\hline $4 \% \mathrm{FCM}$ & 34.0 & 35.1 & 34.6 & 36.6 & 1.27 & 0.21 & 0.08 & 0.63 \\
\hline Fat & 1.40 & 1.48 & 1.43 & 1.54 & 0.06 & 0.30 & 0.02 & 0.72 \\
\hline Protein & 1.05 & 1.05 & 1.13 & 1.13 & 0.04 & $<0.01$ & 0.98 & 0.99 \\
\hline Lactose & 1.47 & 1.48 & 1.52 & 1.56 & 0.06 & 0.13 & 0.58 & 0.71 \\
\hline \multicolumn{9}{|l|}{ Milk composition } \\
\hline Fat, $\%$ & 4.38 & 4.62 & 4.36 & 4.53 & 0.21 & 0.58 & 0.04 & 0.74 \\
\hline Protein, \% & 3.26 & 3.27 & 3.43 & 3.33 & 0.07 & $<0.01$ & 0.16 & 0.12 \\
\hline Lactose, $\%$ & 4.55 & 4.60 & 4.60 & 4.62 & 0.03 & 0.09 & 0.11 & 0.34 \\
\hline $\begin{array}{l}\text { MUN, mg/dL } \\
\text { Efficiency, } \mathrm{kg} / \mathrm{kg}\end{array}$ & 12.5 & 11.9 & 10.9 & 9.71 & 0.54 & $<0.001$ & 0.02 & 0.44 \\
\hline Milk/DMI & 1.43 & 1.44 & 1.43 & 1.43 & 0.05 & 0.86 & 0.90 & 0.73 \\
\hline $4 \% \mathrm{FCM} / \mathrm{DMI}$ & 1.50 & 1.57 & 1.50 & 1.54 & 0.04 & 0.61 & 0.08 & 0.63 \\
\hline
\end{tabular}

${ }^{1} \mathrm{BUT}=$ diet containing butyrate; $\mathrm{CON}=$ control diet; INT $=$ interaction between dietary starch content and butyrate supplementation. 
Table 3. Effects of butyrate supplementation and dietary starch content on serum concentration of metabolites and plasma concentration of insulin $^{1}$

\begin{tabular}{|c|c|c|c|c|c|c|c|c|}
\hline Item & \multicolumn{2}{|c|}{ Low starch } & \multicolumn{2}{|c|}{ High starch } & SEM & \multicolumn{3}{|c|}{$P$-value } \\
\hline $\mathrm{BHB}, \mathrm{m} M$ & 0.776 & 0.946 & 0.635 & 0.914 & 0.05 & 0.02 & $<0.001$ & 0.13 \\
\hline Glucose, $\mathrm{mg} / \mathrm{dL}$ & 57.4 & 56.7 & 59.3 & 58.3 & 1.96 & 0.22 & 0.54 & 0.94 \\
\hline Urea N, mg/dL & 13.2 & 12.1 & 11.1 & 9.94 & 0.44 & $<0.001$ & $<0.001$ & 0.92 \\
\hline Insulin, ng/mL & 5.87 & 6.04 & 6.58 & 6.65 & 0.33 & 0.04 & 0.71 & 0.88 \\
\hline
\end{tabular}

${ }^{1} \mathrm{BUT}=$ diet containing butyrate; $\mathrm{CON}=$ control diet; INT $=$ interaction between dietary starch content and butyrate supplementation.

dietary starch content. Milk protein concentration and yield were higher for cows fed HS diets than for cows fed LS diets $(P<0.01)$, but were not affected by butyrate treatment. Concentration of MUN was lower for cows fed HS diets $(P<0.001)$ and butyrate diets $(P$ $=0.02$ ) compared with those fed LS and control diets, respectively.

Serum concentration of BHB was lower in cows fed HS diets $(P=0.02)$ but higher for butyrate diets $(P$ $<0.001)$ compared with cows fed HS and control diets, respectively (Table 3 ). Dietary starch content and butyrate supplementation did not affect serum concentration of free fatty acids and glucose. The serum concentration of UN was lower for cows fed HS and butyrate diets $(P<0.001)$ compared with those fed LS and control diets, respectively. Cows fed HS diets had higher plasma insulin concentration than those fed LS diets $(P=0.04)$.

The effects of butyrate administration on the productivity of lactating cows have not been extensively studied in the past partly because substantial amount of butyrate is already produced by rumen fermentation (Bergman, 1990) and excess butyrate supply may increase the risk of ketosis (Holtenius and Holtenius, 1996; Driehuis et al., 2018). In the current study, butyrate supplementation at $1.1 \%$ of diet DM increased serum BHB concentration compared with control, but did not exceed $1.2 \mathrm{~m} M$, the threshold value for subclinical ketosis (Suthar et al., 2013; Nydam et al., 2017), and neither DMI nor milk yield decreased. Urrutia et al. (2019) reported that butyrate supplementation at $2.0 \%$ of diet DM (2.5\% as calcium butyrate) decreased DMI and milk yield compared with control, but our study suggested that butyrate supplementation up to $1.1 \%$ of diet DM would not be associated with negative effects on DMI and milk production.

Butyrate treatment increased the concentration and yield of milk fat compared with control, and as a result, tended to increase FCM yield and FCM production efficiency. Because the $\mathrm{NE}_{\mathrm{L}}$ content of our butyrate diets was higher than the control diets by $0.04 \mathrm{Mcal} / \mathrm{kg}$ of DM, greater energy intake cannot be excluded as a rea- son for the greater FCM yield for butyrate treatment. However, although the $\mathrm{HS}$ diets were higher in $\mathrm{NE}_{\mathrm{L}}$ content than the LS diets by $0.05 \mathrm{Mcal} / \mathrm{kg}$ of DM, FCM yield was not affected, indicating that greater milk fat and FCM yields in the current study are likely attributable to a greater supply of BHB for de novo fatty acids in the mammary gland (Dils, 1986; Maxin et al., 2011). Huhtanen et al. (1993) infused isoenergetic VFA mixture solutions, varying in butyrate content, into the rumen of lactating dairy cows, and reported that butyrate infusion linearly increased milk fat yield even with similar energy intake. In contrast, Urrutia et al. (2019) reported that calcium butyrate supplementation decreased milk fat yield compared with control, but their control diet contained sodium bicarbonate at $3.2 \%$ of dietary DM, and calcium butyrate supplementation decreased DMI by $2.6 \mathrm{~kg} / \mathrm{d}$. Based on a meta-analysis, Maxin et al. (2011) reported that butyrate addition increased concentration and milk fat yield, and that its effects were greater than acetate. These facts suggest that butyrate supplementation can increase milk fat production unless DMI is decreased.

We found that both HS diets and butyrate supplementation decreased serum UN and MUN. The effects of HS diets were expected because of greater ruminal starch fermentation, but it is noteworthy that butyrate diets decreased serum N and MUN. Infusion of butyrate into the rumen has been shown to cause a profound effect on the rumen microbial composition ( $\mathrm{Li}$ et al., 2012) and reduce the concentration of ammonia nitrogen in the rumen fluid (Herrick et al., 2017). These researchers suggested that butyrate administration may promote the growth of rumen microorganisms; as the growth efficiency of rumen microorganisms increases, the utilization of ammonia nitrogen in the rumen increases, decreasing serum UN and MUN. However, greater microbial protein production would have increased MP supply to the duodenum, which should have increased milk protein production (NRC, 2001). In fact, cows fed HS diets increased their milk protein yield compared with those fed LS diets, possibly because greater ruminal fermentation increased microbial 
protein production. However, a similar increase in milk protein yield was not observed for butyrate treatment. This might have been because butyrate treatment increased protozoa mass, rather than bacterial N production, for some reason; protozoa can actively prey on rumen bacteria (Jouany and Ushida, 1999) and also be sequestered in the reticulum without flowing to the lower gut (Abe et al., 1981), decreasing microbial N flow to the duodenum (Ushida et al., 1986).

Alternatively, butyrate supplementation might have increased $\mathrm{N}$ use by ruminal epithelial tissues. Norton et al. (1982) reported that intraruminal infusion of sodium butyrate for 2 wk decreased serum urea concentration and increased urea clearance to the rumen in sheep. Simmons et al. (2009) observed that ruminal butyrate increased the expression of urea transporter and rumen papillae length. This evidence suggested that elevation of ruminal butyrate would enhance urea $\mathrm{N}$ recycling by increasing protein synthesis of rumen epithelial tissues (Agarwal et al., 2015). These observations are consistent with our findings, where butyrate treatment decreased serum UN and MUN without increasing milk protein yield, but further research is warranted to investigate effects of butyrate on $\mathrm{N}$ metabolism of lactating dairy cows.

In conclusion, animal responses to butyrate supplementation in DMI and milk production were not affected by dietary starch content in the current study. Inclusion of butyrate at $1.1 \%$ of dietary DM increased milk fat production, regardless of dietary starch content, without decreasing DMI or increasing the risk of subclinical ketosis. Butyrate supplementation also decreased MUN without increasing milk protein yield, and the effects of butyrate on $\mathrm{N}$ metabolism warrant further research.

\section{ACKNOWLEDGMENTS}

The authors thank students of Ruminology and Herd Health units and staff of Rakuno Gakuen Field Education and Research Center (Ebetsu, Japan) for their technical assistance. This work was financially supported by Rakuno Gakuen University Research Fund (\#201803; Ebetsu, Japan), Japan Society for the Promotion of Science (\#18K1493, \#L18535; Tokyo, Japan), and Natural Sciences and Engineering Research Council of Canada (\#RES0043386; Ottawa, ON, Canada).

\section{REFERENCES}

Abe, M., T. Iriki, N. Tobe, and H. Shibui. 1981. Sequestration of holotrich protozoa in the reticulo-rumen of cattle. Appl. Environ. Microbiol. 41:758-765.
Agarwal, U., Q. Hu, R. L. Baldwin, and B. J. Bequette. 2015. Role of rumen butyrate in regulation of nitrogen utilization and urea nitrogen kinetics in growing sheep. J. Anim. Sci. 93:2382-2390.

AOAC International. 2000. Official Methods of Analysis. 17th ed. AOAC Int., Gaithersburg, MD.

AOAC International. 2006. Official Methods of Analysis. 18th ed. AOAC Int., Gaithersburg, MD.

Bergman, E. N. 1990. Energy contributions of volatile fatty acids from the gastrointestinal tract in various species. Physiol. Rev. $70: 567-590$.

Dils, R. R. 1986. Comparative aspects of milk fat synthesis. J. Dairy Sci. 69:904-910.

Driehuis, F., J. M. Wilkinson, Y. Jiang, I. Ogunade, and A. T. Adesogan. 2018. Silage review: Animal and human health risks from silage. J. Dairy Sci. 101:4093-4110.

Ferguson, J. D., D. T. Galligan, and N. Thomsen. 1994. Principal descriptors of body condition score in Holstein cows. J. Dairy Sci 77:2695-2703.

Górka, P., Z. M. Kowalski, P. Pietrzak, A. Kotunia, W. Jagusiak, and R. Zabielski. 2011. Is rumen development in newborn calves affected by different liquid feeds and small intestine development? J. Dairy Sci. 94:3002-3013.

Górka, P., Z. M. Kowalski, R. Zabielski, and P. Guilloteau. 2018. Invited review: Use of butyrate to promote gastrointestinal tract development in calves. J. Dairy Sci. 101:4785-4800.

Hall, M. B. 2009. Analysis of starch, including malt oligosaccharides, in animal feeds: A comparison of methods and a recommended method for AOAC collaborative study. J AOAC Int. 92:42-49.

Harvatine, K. J., Y. R. Boisclair, and D. E. Bauman. 2009. Recent advances in the regulation of milk fat synthesis. Animal 3:40-54.

Herrick, K. J., A. R. Hippen, K. F. Kalscheur, D. J. Schingoethe, D. P. Casper, S. C. Moreland, and J. E. van Eys. 2017. Singledose infusion of sodium butyrate, but not lactose, increases plasma $\beta$-hydroxybutyrate and insulin in lactating dairy cows. J. Dairy Sci. 100:757-768.

Herrick, K. J., A. R. Hippen, K. F. Kalscheur, D. J. Schingoethe, S. D. Ranathunga, J. L. Anderson, S. C. Moreland, and J. E. van Eys. 2018. Infusion of butyrate affects plasma glucose, butyrate, and $\beta$-hydroxybutyrate but not plasma insulin in lactating dairy cows. J. Dairy Sci. 101:3524-3536.

Holtenius, P., and K. Holtenius. 1996. New aspects of ketone bodies in energy metabolism of dairy cows: A review. Zentralbl. Veterinarmed. A. 43:579-587.

Huhtanen, P., H. Miettinen, and M. Ylinen. 1993. Effect of increasing ruminal butyrate on milk yield and blood constituents in dairy cows fed a grass silage-based diet. J. Dairy Sci. 76:1114-1124.

Jouany, J. P., and K. Ushida. 1999. The role of protozoa in feed digestion - review. Asian-Australas. J. Anim. Sci. 12:113-128.

Kmicikewycz, A. D., K. J. Harvatine, and A. J. Heinrichs. 2015. Effects of corn silage particle size, supplemental hay, and forageto-concentrate ratio on rumen $\mathrm{pH}$, feed preference, and milk fat profile of dairy cattle. J. Dairy Sci. 98:4850-4868.

Li, R. W., S. Wu, R. L. Baldwin 6th, W. Li, and C. Li. 2012. Perturbation dynamics of the rumen microbiota in response to exogenous butyrate. PLoS One 7:e29392.

Masuda, Y., R. Fukumori, R. Yanai, A. Takeuchi, S. Borjigin, T. Sugino, and Y. Nagao. 2019. Effects of supplementation with calcium salts of medium-chain fatty acids on the plasma metabolic hormone concentrations in weaning beef calves. Anim. Behav. Manage. 55:82-93.

Maxin, G., H. Rulquin, and F. Glasser. 2011. Response of milk fat concentration and yield to nutrient supply in dairy cows. Animal 5:1299-1310.

Norton, B. W., A. N. Janes, and D. G. Armstrong. 1982. The effects of intraruminal infusions of sodium bicarbonate, ammonium chloride and sodium butyrate on urea metabolism in sheep. Br. J. Nutr. $48: 265-274$.

NRC. 2001. Nutrient Requirements of Dairy Cattle. 7th rev. ed. Natl. Acad. Sci., Washington, DC. 
Nydam, D. V., T. R. Overton, J. A. A. McArt, M. M. McCarthy, B. Leno, and S. Mann. 2017. Management of transition cows to optimize health and production. Pages 1067-1076 in Large Dairy Herd Management. 3rd ed. D. K. Beede, ed. American Dairy Science Association, Champaign, IL.

Rook, J. A. F., C. C. Balch, and V. W. Johnson. 1965. Further observations on the effects of intraruminal infusions of volatile fatty acids and of lactic acid on the yield and composition of the milk of the cow. Br. J. Nutr. 19:93-99.

Sakata, T., and H. Tamate. 1978. Rumen epithelial cell proliferation accelerated by rapid increase in intraruminal butyrate. J. Dairy Sci. 61:1109-1113.

Simmons, N. L., A. S. Chaudhry, C. Graham, E. S. Scriven, A. Thistlethwaite, C. P. Smith, and G. S. Stewart. 2009. Dietary regulation of ruminal bovine UT-B urea transporter expression and localization. J. Anim. Sci. 87:3288-3299.

Suthar, V. S., J. Canelas-Raposo, A. Deniz, and W. Heuwieser. 2013. Prevalence of subclinical ketosis and relationships with postpartum diseases in European dairy cows. J. Dairy Sci. 96:2925-2938.
Urrutia, N., R. Bomberger, C. Matamoros, and K. J. Harvatine. 2019 Effect of dietary supplementation of sodium acetate and calcium butyrate on milk fat synthesis in lactating dairy cows. J. Dairy Sci. 102:5172-5181.

Ushida, K., J. P. Jouany, and P. Thivend. 1986. Role of rumen protozoa in nitrogen digestion in sheep given two isonitrogenous diets. Br. J. Nutr. 56:407-419.

Van Soest, P. J., J. B. Robertson, and B. A. Lewis. 1991. Methods for dietary fiber, neutral detergent fiber, and nonstarch polysaccharides in relation to animal nutrition. J. Dairy Sci. 74:3583-3597.

Wanat, P., P. Górka, and Z. M. Kowalski. 2015. Short communication: Effect of inclusion rate of microencapsulated sodium butyrate in starter mixture for dairy calves. J. Dairy Sci. 98:2682-2686.

\section{ORCIDS}

M. Oba ๑ https://orcid.org/0000-0001-8057-3500 